\title{
The Impact of Covid-19 on Malaysia Tourism Industry Supply Chain
}

Rasidah Hamid, Nor Hanisah Mohd Hashim, Shamsul Azren Mohd Shukur, Najihah Hanisah Marmaya

To Link this Article: http://dx.doi.org/10.6007/IJARBSS/v11-i16/11213 DOI:10.6007/IJARBSS/v11-i16/11213

Received: 07 July 2021, Revised: 10 August 2021, Accepted: 29 August 2021

Published Online: 22 September 2021

In-Text Citation: (Hamid et al., 2021)

To Cite this Article: Hamid, R., Hashim, N. H. M., Shukur, S. A. M., \& Marmaya, N. H. (2021). The Impact of Covid-19 on Malaysia Tourism Industry Supply Chain. International Journal of Academic Research in Business and Social Sciences, 11(16), 27-41.

Copyright: (C) 2021 The Author(s)

Published by Human Resource Management Academic Research Society (www.hrmars.com) This article is published under the Creative Commons Attribution (CC BY 4.0) license. Anyone may reproduce, distribute, translate and create derivative works of this article (for both commercial and non-commercial purposes), subject to full attribution to the original publication and authors. The full terms of this license may be seen at: http://creativecommons.org/licences/by/4.0/legalcode

Special Issue Title: Contemporary Issues in Tourism and Hospitality industry, 2021, Pg. 27 - 41

Full Terms \& Conditions of access and use can be found at http://hrmars.com/index.php/pages/detail/publication-ethics 


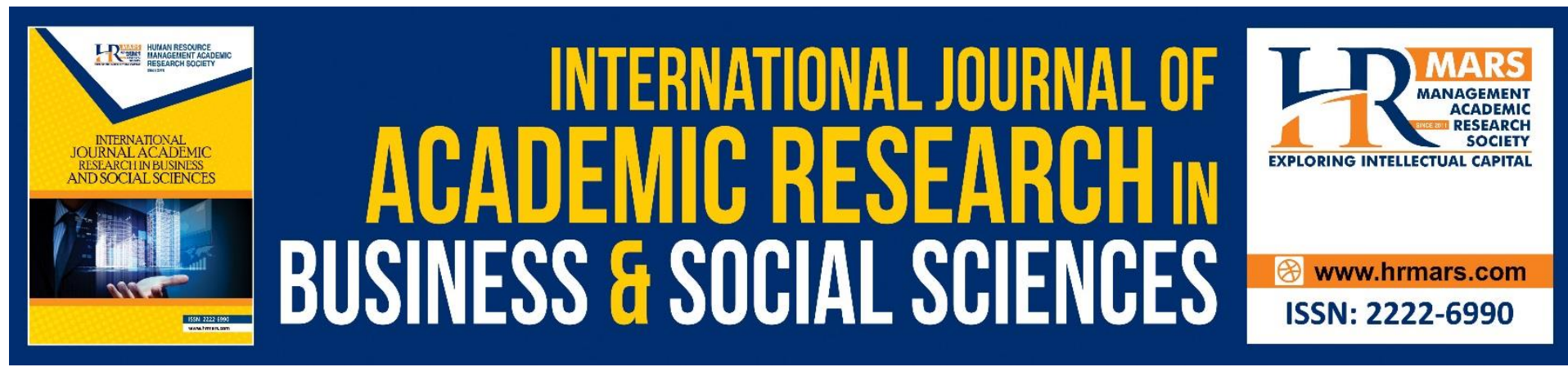

\section{The Impact of Covid-19 on Malaysia Tourism Industry Supply Chain}

\section{Rasidah Hamid'1 Nor Hanisah Mohd Hashim², Shamsul Azren Mohd Shukur ${ }^{3}$, Najihah Hanisah Marmaya ${ }^{4}$}

${ }^{1}$ Faculty of Hotel \& Tourism Management, Universiti Teknologi MARA, 42300 Puncak Alam, Selangor, Malaysia, ${ }^{2}$ Faculty of Architecture, Planning \& Surveying, Universiti Teknologi MARA, 40450 Shah Alam, Selangor, Malaysia, ${ }^{3}$ Faculty of Business and Management, Universiti Teknologi MARA, 42300 Puncak Alam, Selangor, Malaysia, ${ }^{4}$ Faculty of Business and Management, Universiti Teknologi MARA, 75300 Melaka, Malaysia

\section{Abstract}

This research addresses the effect of COVID-19 on the tourism industry in general and on Malaysia in particular. This research explores the impact that the COVID-19 crisis has had on the tourism and tourism industry and hospitality services trends. To achieve the purpose of this research, first, the article explores the impact of the COVID-19 crisis on the impacts of the tourism industry, behaviours, and experiences for societal inclusion, together with international tourism disruption caused by Covid-19. The article discusses the significant impacts and experiences of COVID-19 on selected tourism supply chain members in Malaysia. Then, this paper provides a quick assessment of the reported procedures of the three major tourism stakeholders in Malaysian tourism (i.e., tourism demand, supply, government, and policymakers). This article finally draws on observation and reflections about the evolution of social inclusion through new forms of creative and niche tourism, accelerated by the COVID19 crisis. For better or worse, an overview of the COVID-19 tourism impacts and implications thus suggests mitigation strategies for tourism research. Despite the industry's resilience in response to previous crises, the sheer depth and breadth of COVID-19- related impacts on tourism and the economy means a quick recovery is unlikely.

Keywords: Covid-19, Malaysia, Tourism Supply Chain, Hospitality Industry.

\section{Introduction}

The growing importance and severeness to tourism have revolutionized from an economic, socio-cultural, and pro-environmental perspective (Buckley, 2020). The socioeconomic impacts (Mihajlovic, 2020) are massive and will affect millions of people, both now and in the future. In response to various crises and outbreaks, the Covid-19 has demonstrated remarkable resilience. The COVID-19 (Mihajlovic, 2020) significantly impacts the global economic, political, and socio-cultural systems. In Asia, 100\% of destinations have adopted restrictions related to COVID19 since January 2020 (ILO, 2020). In Malaysia, Malaysian Associations of Hotels (MAH, 2020) estimated that the hotel, aviation, and travel sector lost about 5.6 billion in revenue due to travel restrictions. The resilient nature, the unprecedented 
impacts, COVID-19s show that the crisis has the potential to have far-reaching and long-term impacts on tourism as an economic industry (Razak, 2020). They considered the strategies and measures (e.g., travel and mobility bans, community lockdowns, social distancing, stay at home campaigns, self- or mandatory quarantine, curbs on crowding) that have stopped global travel and tourism, which severely caused damages to national and international economies.

The Covid-19 impact on the tourism industry is the highest affected sector. Tourism and hospitality are among the most affected sectors, indicating the direct and indirect economic consequences and damages associated with COVID-19. The impact varies across industries. The tourism industry involving face-to-face interactions is likely to be disproportionally affected, including hotels and restaurants, air travel, and tourism services.

The COVID-19 Pandemic has triggered an impact on the world's demand and supply of products and services. Domestic tourism represents around $75 \%$ of tourism economies in countries that are likely to drop significantly (Razak, 2020). The complex and challenging demand would fall due to foreign buyers delaying or withdrawing orders, local and foreign tourists, canceling trips, and the drops in the stock market (Salman et al., 2021). On the other hand, the supply side also faces disruptions in developing countries due to imported raw materials and spare parts (Singh \& Misra, 2020). According to the UNWTO (2020), tourism is one of the most significant economic employers worldwide, and tourism is one of the leading contributors to GDP in developed countries such as Malaysia. An analysis is essential. According to the UNWTO (2020), tourism is one of the most significant economic employers worldwide, and tourism is one of the leading contributors to GDP in developed countries such as Malaysia. Therefore, an analysis is essential. As for now, there are growing industry overwhelmed discussions and research about tourism and COVID-19. There is a universal call to see and use the pandemic as a transformative opportunity. The industry should not only recover but also reform and reimagine the following routine and economic order (Singh \& Misra, 2020),

Malaysia has been highly an emerging economy in recent years with increased instability, and the tourism sector recorded its highest revenues in 2018/19. Continued efforts to improve Malaysia's business climate thus could lead to more robust private sector growth and economic diversification in 2020 and beyond (Foo et al., 2020). Malaysia's recent financial success and ongoing reform efforts will almost certainly be interrupted by the COVID-19 pandemic. While the government is taking action to contain the spread of the virus, international travel restrictions are already limiting tourism to the country (Foo et al., 2020). Therefore, this article proposes to look at the effect of COVID-19 on the tourism industry in general and Malaysian tourism in particular.

\section{Literature Review}

This paper is based on an overview of the relevant literature on the travel and tourism industry and hospitality service trends. To achieve the objective of this article, first, the article looks at the impact of COVID-19 as a global tourism disruption. The research was done on the different tourist industries that were negatively impacted by the pandemic. The research was done on the different tourist industries that were negatively impacted by the pandemic. The paper discusses the significant effects, behaviours, and experiences of COVID-19 on selected tourism supply chain members in Malaysia. Then, the article provides a rapid assessment of the reported procedures of the three major tourism stakeholders in Malaysian tourism (namely tourism demand, supply the government, and policymakers) concerning response and recovery phases. To summarise, tourism industry resilience efforts in the near future. 


\section{COVID -19 as an International Tourism Disruption}

The COVID-19 Pandemic has heavily hit the tourism industry. Research investigating the COVID-19 tourism impacts is important to develop recovery measures, monitor and improve response strategies (Škare et al., 2021). The impact of COVID 19 could be felt throughout the entire tourism ecosystem. This unprecedented crisis led to a combination of a natural disaster, a socio-political, economic, and tourism demand crisis (Beh \& Lin, 2021). This pandemic Covid-19 is more global and has a much longer period effect compared to the previous health-related crisis. In comparison, tourism studies such as SARS in 2003, the H1N1 outbreak in 2009, and MERS in 2015 show comparable patterns on smaller scales (Salman et al., 2021). The scenarios are similar between an economic recession caused by a coronavirus and 2008 and the political aspect of the pandemic and investigations into tourism during the Arab Spring uprising and the refugee crisis (Brown et al., 2017)

COVID-19 tourism impacts are uncertain outlook in relation to time and space, where early estimation shows an enormous within international economic impact: One prediction from the United Kingdom indicates that tourism expenditure (overnight and same-day trips) will decrease by 24 percent, equaling GBP 22.1 billion and surpassing the international loss of GBP 19.7 billion in absolute value (Al-Rohaimi \& Al Otaibi, 2020). A 50 percent revenue drop was shown by the global leisure and internal tourism figures, which adds up to a lowering of more than 2.86 trillion US dollars. The current pandemic Covid-19 has been estimated drop of international tourist arrivals of 78\%, causing a loss of US\$1.2 trillion in export revenues from tourism and 120 million direct tourism job cuts representing seven times the impact of September 11 and the largest decline in the history (UNWTO, 2020). Since late December 2019, the advent of the global tourism economy contracted has developed unprecedented global health crises, social emergencies, and profound adverse consequences on the global economy (ILO, 2020). People who have lost their jobs because of travel restrictions and business closures have put a huge strain on the leisure industry (Mihajlovic, 2020). The change might contribute to economic consequences that are expected to vary across countries, depending on how massively the spread and intensity of the pandemic and associated government responses are (Ruiz, 2020). The tourism industry falls among the significant vulnerable industries affected globally. There are major industry-wide consequences to the current pandemic COVID-19, including renewable energy, carbon emission, economic, and healthcare crises and risks. It has prompted travel and tourism-related service industries to struggle (Abbas et al., 2021).

The human-centered future of work is predicted to be clouded by the disaster of the COVID-19 pandemic. This catastrophic virus is expected to have erased over 81 million jobs in 2020, according to forecasts. Most economies had reduced employment levels in 2020 when compared to 2019. The Covid-19 Pandemic has made the tourism industry decrease the sector and also the economic problem. It causes bunches of the worker being fired, or the termination of employment has been increasing significantly (Mihajlovic, 2020).

The world has been devastated by the COVID-19 pandemic. The virus has affected all parts of the hospitality value chain. As has occurred in many countries, tourism businesses worldwide went from being relatively stable operations to facing potential bankruptcy with the reduction of workers and negotiated pay cuts for others. The impact of being overwhelmed by the increase in room booking cancellations, cancelled events, closed accommodations, and immense shutdown attractions immediately felt in other parts of the supply chain - the catering, laundry services, and restaurants (Foo et al., 2020). Furthermore, COVID-19 affects the tourism industry worldwide. All the international flights are grounded, 
cross-border activity is discouraged if not barred, tourism demands are dwindling, and loss of jobs further aggravates people's ability to indulge themselves. Many industries are affected and require a wide spectrum of agencies to pitch in and solve the problem (Yeh, 2021). This is how these industries expect to be impacted:

- Airlines: A 60\% decline in the Airline's global seat and a 2,699 million decline in passenger numbers between 2019 and 2020, with airlines reporting a loss of approximately $\$ 371$ billion in gross passenger operating revenue in 2020 (Chowdhury \& Chhikara, 2020). Increased cost due to travel restrictions for airlines, including costs for disinfection and temperature control (Keeling, 2020).

- Cruise Industry: The Norwegian Jewel in the Pacific Ocean was denied docking at the previously scheduled ports in New Zealand and Australia. However, there were no suspected or confirmed cases of COVID-19. The Pacific Princess, which embarked on its 111 days' voyage in January 2020, announced the closure of its operations within 60 days due to COVID-19-related fears as it was denied entry to scheduled ports and so disembarked guests at convenient locations (Morecroft, 2020).

-

- Hotels: $71 \%$ of hotels won't make it another six months without further federal assistance, given current and projected travel demand. $77 \%$ will be forced to lay off more workers. Without further government assistance (i.e. financial loan, expansion of Main Street Lending Program), nearly half (47\%) of respondents indicated they would be forced to close hotels (DEMiR et al., 2021). More than one-third of hotels will be facing bankruptcy or be forced to sell by second quarter of 2021 .

\section{Tourism in Malaysia}

Travel and tourism are important sector in Malaysia with a strong linkage to many parts of the economic contribution, direct and indirect (Abbas et al., 2021). The tourism industry in Malaysia placed the third largest contributor to the economy of the country. The national tourism industry recorded a positive tourist arrivals growth of $4.8 \%$ for the January until May 2019 period, registering a total of 10,954,014 tourist arrivals compared to 10,454,447 in the same period last year. According to the (Uzir, 2019), the Gross Value Added of Tourism Industries (GVATI) has recorded that the tourism industry contributed 15.2\% to Malaysia's GDP compared to $14.6 \%$ in 2019. The Ministry of Tourism, Arts and Culture Malaysia launched Malaysia Integrated Plan 2018-2020 (Tourism Malaysia 2018) to promote Malaysia's extensive tourism offering further and boost tourist arrivals and receipts. Revenues from tourism contributed RM12Millions (4.2 percent of GDP) to the Malaysian economy (Muadz Samat, 2020). The tourism sector is one of the largest employers in Malaysia, providing 3.1 million jobs or $9.5 \%$ of the total workforce (Uzir, 2019).

In 2020, Malaysia recorded 4.3 million international arrivals, a decrease of $83 \%$ compared to the previous year due to Covid-19. Before the Covid-19 Pandemic, most international tourist arrivals were from European countries (60\%). Arrivals from Germany, Ukraine, and the United Kingdom make up nearly a quarter of all arrivals to the Middle East, while arrivals from Saudi Arabia and Jordan, and African countries account for over seven percent. Domestic tourism provides another mechanism to increase the industry's vibrancy further, highlighting Malaysia's uniqueness and strengths through targeted promotional activities (Perimbanayagam, 2020). This is why Malaysia's tourism industry is shifting to even more knowledge-intensive areas, and as a matter of fact, Malaysia's tourism sector is offering more high-income jobs and is transforming from high volume to high yield. Five key areas of 
emphasis will be included in future tourism initiatives, such as enhancing (Perimbanayagam, 2020)the quality of service, boosting marketing promotions, improving governance, and boost domestic tourism.

The National Tourism's development plan, which sought to boost tourist arrivals to Malaysia, had achieved its objectives, leading to a jump in tourist numbers before the Covid19 Pandemic struck. In addition, there were drops in certain years due to both internal and external environmental issues. The graphic below illustrates the growth path of the Malaysian tourism industry.

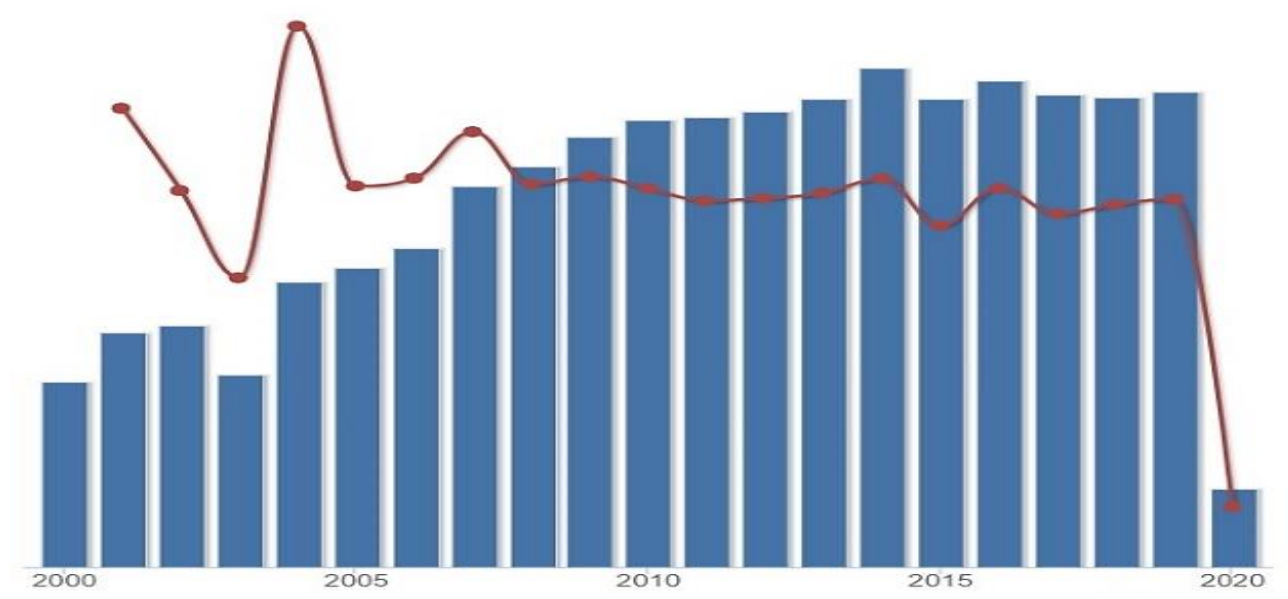

Figure 1: Malaysia Tourist Arrivals (Ministry of Tourism, Art and Culture, 2021)

\section{COVID-19 and the Malaysian tourism industry}

The threat of COVID-19 became more evident in Malaysia after Singapore (a neighbouring country) announced its first imported COVID-19 case from Wuhan, China, on January 23, 2020, which was also the republic's first positive case. Eight close contacts were found in Johor, Malaysia, as a result of the first instance. In Malaysia, the first such case was found on January 25, 2020. A case imported from Wuhan, China, was brought in (Faizal et al., 2020). Eight positive cases were identified in the space of 6 days, beginning with the first case. The infections were imported from China (Faizal et al., 2020). On February 3, 2020, the first Malaysian who tested positive for COVID-19 claimed having recently returned from a business trip to a neighbouring nation, where they had also met with a delegation from China (Abdullah et al., 2020).

On March 31, 2020, Malaysia addressed all reported instances in three steps. All 22 of the previously mentioned cases were discharged from the hospital on February 27, 2020. China was the primary source of the first wave of reported cases, and the vast majority of the reported cases were those of direct exposure to those who brought the disease to the country. There were just two cases linked to local transmission (Abdullah et al., 2020). World travel has become more challenging in recent days. It is more notable just after the Malaysian government's crackdown on hotels, restaurants, and nightclubs, which happened on March 18, 2020 (Foo et al., 2020). In Figure 2, you can see a downward trend in the tourist receipts in Malaysia, which explained a decrease in the percentage of international visitors. 


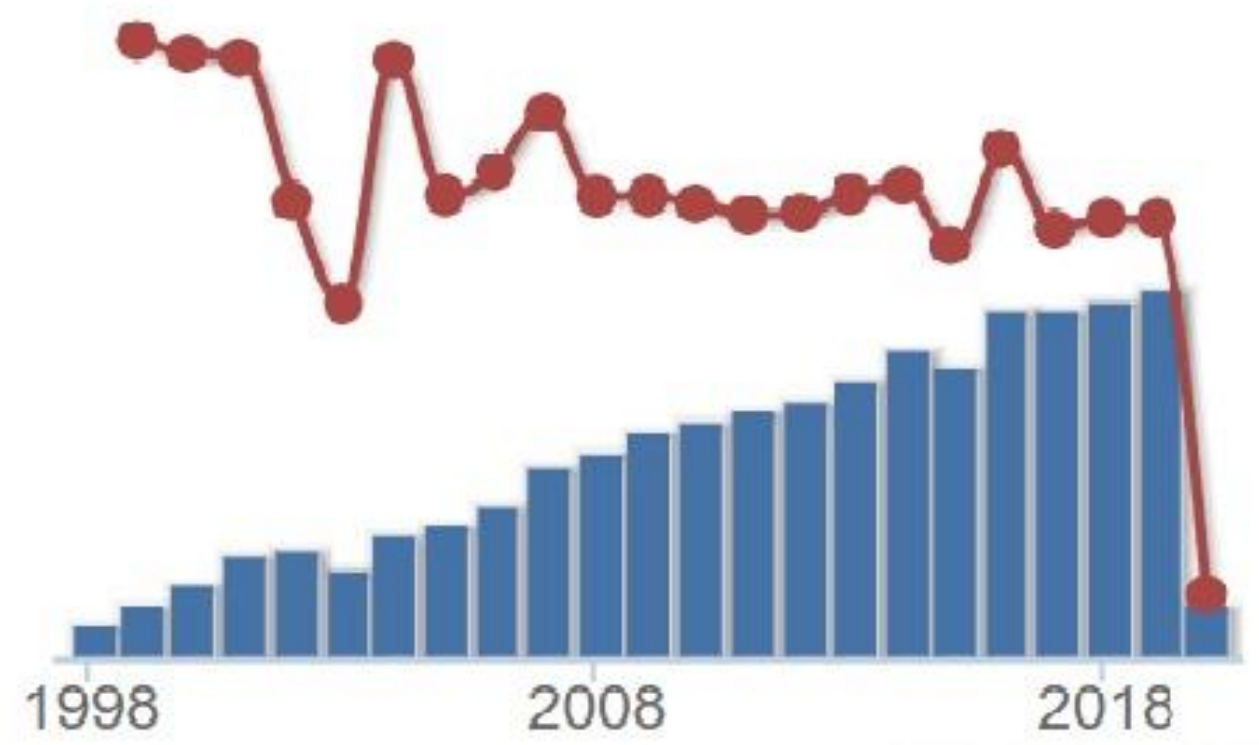

Figure 2: Tourist receipts (Ministry of Tourism, Art and Culture, 2021)

Tourist spending in the first half of the year was cut by more than half due to the spread of the Covid-19 virus. Tourism, Arts, and Culture Minister Datuk Seri Nancy Shukri claimed that the numbers dropped by 68.2 and 69.8 percent, respectively, from the same period the previous year (Perimbanayagam, 2020). RM45 billion in tourist spending was lost in the first half of the year due to the outbreak of the Covid-19 virus. Because of curfews and total-lockdown measures in many cities, the hospitality and tourism industry has become a risky endeavor for people involved in it. Besides, the restaurant, cafe, and bar industries are completely shut down, as well and Tables 1 and 2 show how COVID-19 impacts the key affiliates of tourism supply chain. 
Table 1: Footprint of COVID-19 on selected tourism Supply Chain affiliates

\begin{tabular}{|c|c|}
\hline Supply Chain Affiliates & The Effect \\
\hline Accomodation and Hotels & $\begin{array}{l}\text { - Most hotel bookings being cancelled are between } 70 \text { and } 80 \\
\text { percent (Hamid \& Isa, 2020). } \\
\text { - The hotels have all been cleared by the World Health } \\
\text { Organization, according to government advice. } \\
\text { - Because of that, shared accommodations are not taking place } \\
\text { in many regions. } \\
\text { - Reservation refunds cancelled }\end{array}$ \\
\hline Transportation & $\begin{array}{l}\text { - The administration has banned flights coming into and out of } \\
\text { the country in an effort to contain the international epidemic } \\
\text { (Deb \& Nafi, 2020). }\end{array}$ \\
\hline $\begin{array}{l}\text { Travel Agents and tour } \\
\text { operators }\end{array}$ & $\begin{array}{l}\text { - Several tour operators are infected with COVID-19. } \\
\text { - Malaysian authorities are being ordered to make sure that } \\
\text { travel agencies refund fees to customers travel packages paid } \\
\text { (Hamid \& Isa, 2020). } \\
\text { - Since transactions have slowed down significantly, online } \\
\text { travel agencies and online booking platforms are being } \\
\text { affected as well. }\end{array}$ \\
\hline Restaurants and food supply & $\begin{array}{l}\text { - In the past, food and catering service providers had to widen } \\
\text { social distances in eateries, limit their activities to delivery, or } \\
\text { stop all of their operations (Post, 2020). } \\
\text { - Eating and drinking establishments in the area are required to } \\
\text { close between } 7 \text { p.m. and } 6 \text { a.m. daily in order in order to halt } \\
\text { the virus's proliferation (Lai et al., 2020). }\end{array}$ \\
\hline Related Tourism business & $\begin{array}{l}\text { - The government cleared all tourist locations, and tourist sites } \\
\text { were shut down. } \\
\text { - Event planners and museums are suffering enormous financial } \\
\text { losses because of the closure of venues and cancellation of } \\
\text { events (Muadz Samat, 2020). } \\
\text { - Abandonment of several high-profile events, including the } \\
\text { events such as Le Tour de Langkawi, Visit Malaysia Year etc. }\end{array}$ \\
\hline
\end{tabular}

Before, during, and following a crisis, it is generally agreed that crisis management should be utilized. Table 2 below presents a brief overview of the tourism-related programs launched by Malaysia in response to the COVID-19 crisis. The table highlights the ramifications and impacts of COVID-19 on three major stakeholders (tourism demand, tourism operators, and government and policy makers) under three stages that illustrate the transformational stage envisioned in the post-COVID-19 era. 
Table 2: The Effect of covid-19 on Malaysian Tourism Affiliates

\begin{tabular}{|c|c|c|c|}
\hline & During Covid19 & Recovery & Post Covid19 \\
\hline $\begin{array}{l}\text { Tourism } \\
\text { Demand }\end{array}$ & 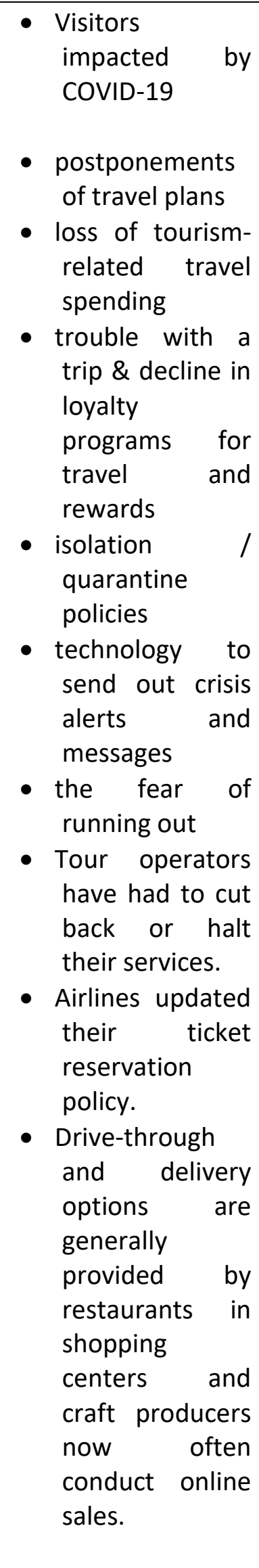 & 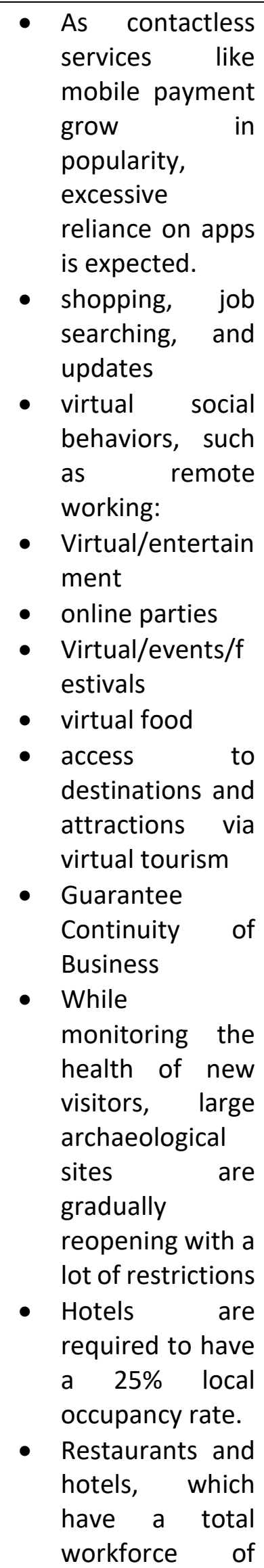 & 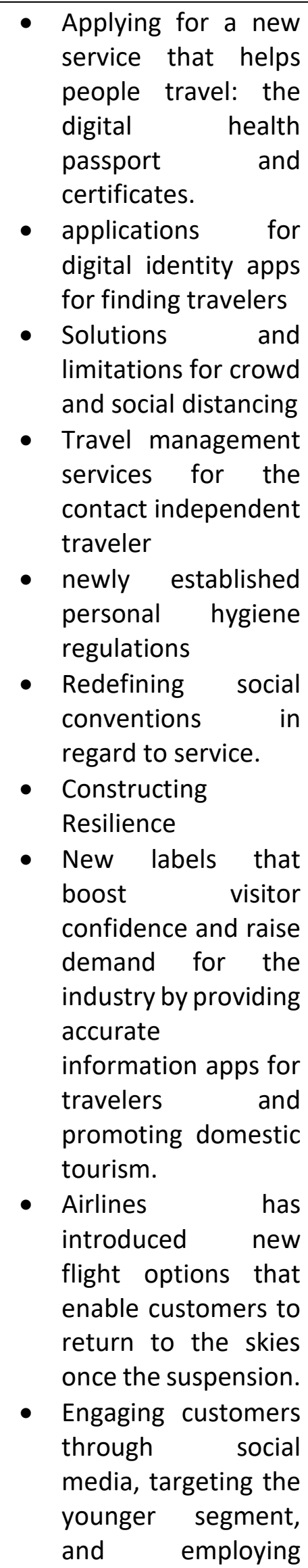 \\
\hline
\end{tabular}




\begin{tabular}{|c|c|c|c|}
\hline & $\begin{array}{l}\text { - (Muadz Samat, } \\
\text { 2020)(Hamid \& } \\
\text { Isa, 2020)(Post, } \\
\text { 2020) }\end{array}$ & $\begin{array}{l}50 \% \text { at a } \\
\text { minimum, } \\
\text { Employees were } \\
\text { educated on the } \\
\text { symptoms and } \\
\text { preventive } \\
\text { measures of } \\
\text { COVID-19 by an } \\
\text { instructor who } \\
\text { had been } \\
\text { trained. } \\
\text { Inbound tourists } \\
\text { are drawn to } \\
\text { hotels and } \\
\text { resorts located } \\
\text { in coastal } \\
\text { governorates } \\
\text { that are } \\
\text { certified. } \\
\text { (Abbas et al., } \\
\text { 2021)(Chowdhur } \\
\text { y \& Chhikara, } \\
\text { 2020)(Muadz } \\
\text { Samat, 2020) }\end{array}$ & $\begin{array}{l}\text { aggressive pricing } \\
\text { tactics. } \\
\text { - (Muadz Samat, } \\
\text { 2020)(Uzir, } \\
\text { 2019)(Hamid \& Isa, } \\
\text { 2020)(Shukla, } \\
\text { 2020)(Post, 2020) }\end{array}$ \\
\hline $\begin{array}{l}\text { Authorities } \\
\text { and } \\
\text { Regulatory }\end{array}$ & $\begin{array}{l}\text { - Ensure the safety } \\
\text { and security of } \\
\text { both tourists } \\
\text { and employees } \\
\text { working in the } \\
\text { tourism industry } \\
\text { are priorities. } \\
\text { - A consolidated } \\
\text { series of } \\
\text { communication } \\
\text { s and directives } \\
\text { issued to the } \\
\text { tourism industry } \\
\text { by Malaysian } \\
\text { Ministries of } \\
\text { Malaysia Board } \\
\text { of Tourism. } \\
\text { - A crisis } \\
\text { Management } \\
\text { Committee was } \\
\text { established to } \\
\text { address } \\
\text { challenges, }\end{array}$ & $\begin{array}{l}\text { - In order to help } \\
\text { resolve the anti- } \\
\text { coronavirus } \\
\text { measures and } \\
\text { return to work, } \\
\text { the government } \\
\text { has proposed a } \\
\text { "coexistence } \\
\text { plan." } \\
\text { - } 10 \text { - } 15 \text { tourists } \\
\text { inside any sites } \\
\text { visit (depending } \\
\text { on its } \\
\text { dimensions). } \\
\text { - To aid 100,000 } \\
\text { families, the } \\
\text { government } \\
\text { extended an } \\
\text { existing cash } \\
\text { transfer } \\
\text { program. The } \\
\text { program } \\
\text { provides several }\end{array}$ & 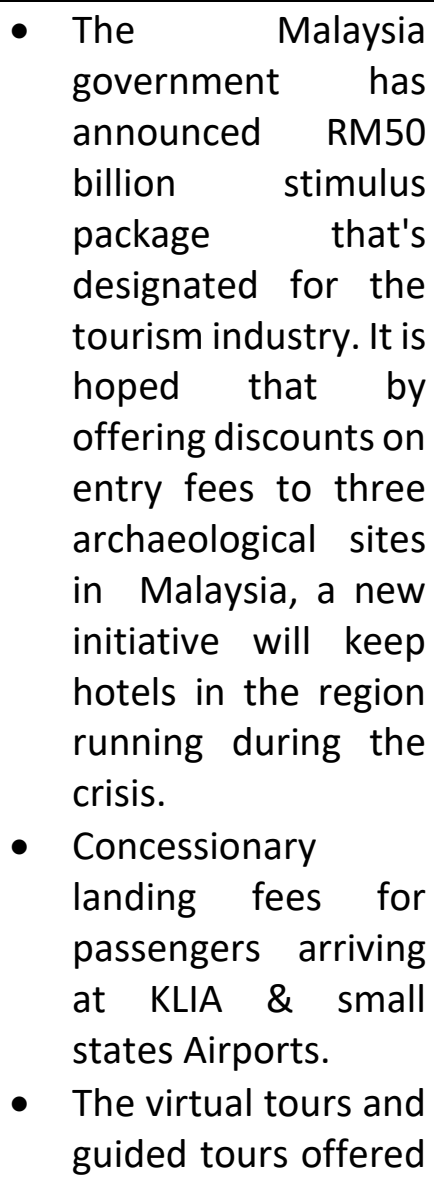 \\
\hline
\end{tabular}




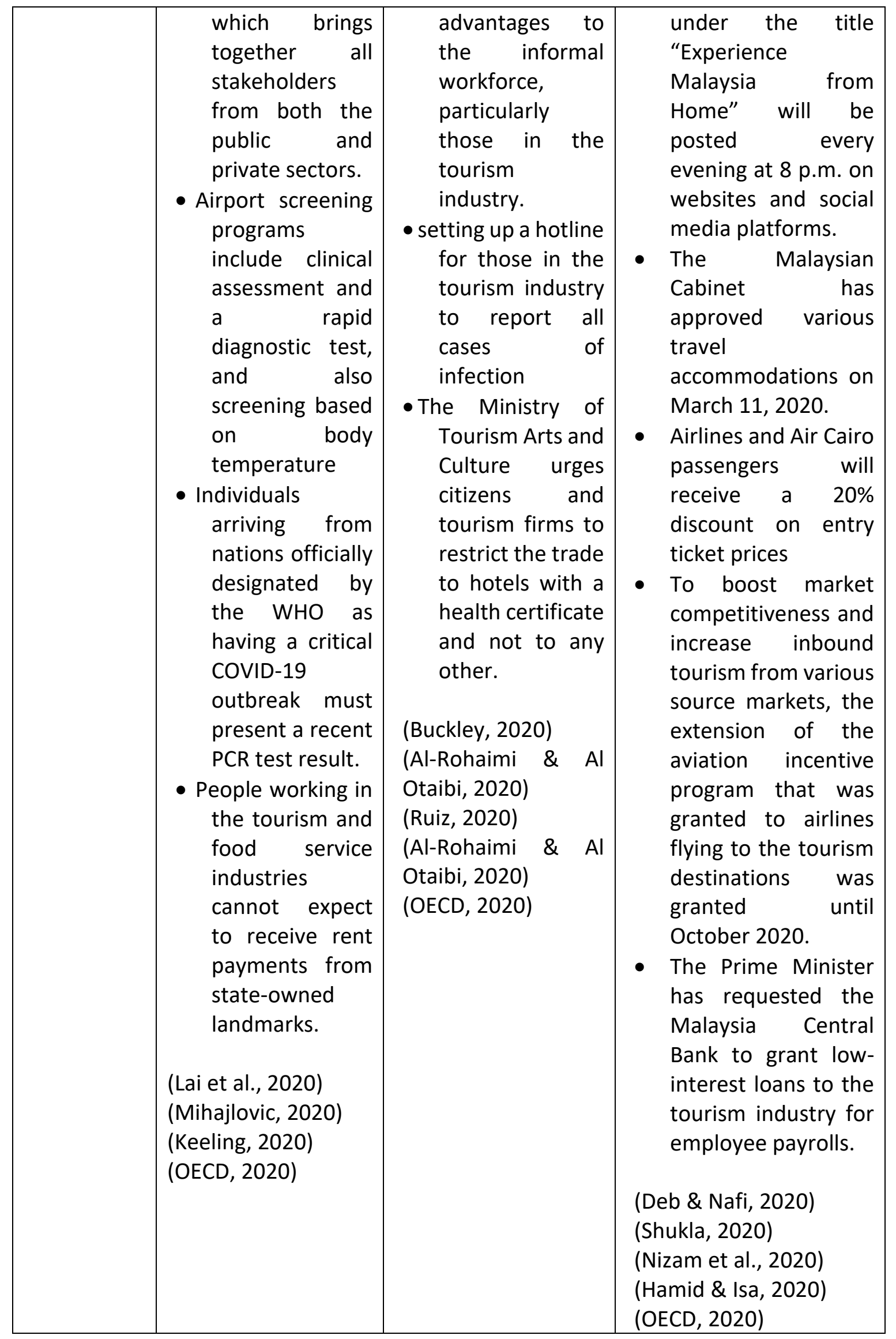




\section{Results and Discussions}

The concept of resilience has become vital in the tourism industry (Chowdhury \& Chhikara, 2020). The bounce back from setbacks is crucial for the tourism industry, as crises and disruptions are detrimental to a destination's image and can linger for a long time. Changes and crises will affect the ability of tourism destinations to recover (Muadz Samat, 2020). This epidemic has hit the tourism industry hard, with countries closing their borders and imposing travel bans on foreigners, which has led to a massive reduction in flights (Beh \& Lin, 2021; OECD, 2020). The tourism industry is an important pillar of many nations' economies, and the large-scale collapse of tourism caused by the epidemic is taking a toll on the broader economy. Even though the pandemic has badly affected tourism and efforts to contain the virus, tourists could help spread the virus if not handled carefully (Al-Rohaimi \& Al Otaibi, 2020). A slower restart and ongoing uncertainty make the sector's task more difficult. Still, rushing could harm the government and consumer confidence, thus putting the sector's long-term viability at risk (Shukla, 2020). This is why it will be more difficult to open the sector than to close it, and it will entail a tempered, measured strategy.

While simultaneously dealing with the tourism industry's reopening, many countries are entering a new phase in fighting the virus. Measuring the effect on the tourism economy is a complex and challenging endeavor (Mihajlovic, 2020). The tourism economy has ground to a halt due to unprecedented restrictions on travel, business operations, and people-to-people interactions, as well as the measures governments around the world, have taken to control the virus. The time frame and pace of the recovery have been delayed and slowed down and is now forecasted to start later than previously thought. The travel restrictions and containment measures will likely last longer and be lifted gradually. The possibility also exists that they could be altered should new waves occur (Post, 2020). Businesses will continue to operate at a limited capacity due to new health protocols, even if Tourism Supply Chain are restored. Consumer confidence and travel habits will be more severely affected the longer the epidemic lasts (Nizam et al., 2020).

Small and micro-businesses will need to follow through on health screening and hygiene measures as they are already being put into place by tourism businesses. In addition, the government should work with national industry associations to assist the industry (OECD, 2020). To keep their employees safe, businesses will need to implement measures to ensure the delivery of tourism services. Many governments have reacted quickly to aid SMEs by implementing policies tailored to their unique circumstances, and this process has tended to unfold in the following order: health protections, deferring payments, supplying extra credit to strengthen SME resilience, and avoiding the consequences of unorganized layoffs (Shukla, 2020).

Given the lack of certainty surrounding international travel, domestic tourism is expected to play a significant role in leading the initial recovery phase. Countries that are heavily dependent on international tourism flows are thus less likely to recover in the tourism industry quickly (OECD, 2020). Travelers are likely to support hotels that offer hygiene and hygiene guarantees in light of the COVID-19 outbreak. To ensure high hygiene standards, hotels should use manual (e.g., staff rounds) and automated (e.g., robot-based) practices to hold out regular hygiene surveillance. As sensors in cleaning robots can measure the amount of dust in a hotel, some robots clean in a more extensive setting in that location, and others generate data that is useful to the cleaning teams (DEMiR et al., 2021)

Malaysia is banking on its domestic tourism industry to provide the momentum for a tourism sector recovery and support. Restrictions on the movement of people have also 
heavily affected domestic tourism flows, but these are expected to rebound once control measures are lifted. In the wake of the crisis, it is time to rethink Malaysia's tourism system to have a more sustainable and robust future. The COVID-19 response can catalyze the reinvention of the tourism industry's supply chain. The goal is to preserve the short-term elements of today's struggle, which can serve as the basis for a future more responsive and flexible operation.

\section{Conclusion}

Due to the current economic situation, tourism is one of the most directly affected sectors and, as such, needs immediate and long-term recovery responses. Because of an international air travel crisis, tourism sites and attractions closed, major festivals and events were rescheduled or canceled, and many countries imposed public gatherings (indoor and outdoor) restrictions. The international tourism impact of COVID-19 was overwhelming and immediate. The first tourism businesses to be closed were in response to measures aimed at containing the virus. It is also possible that tourism activities will take longer to restart and may start-up only after other businesses and services have continued. Regardless of whether they reopen, their operations will be under different rules. The pandemic may also affect the behavior of tourists, influencing the ability of domestic and international tourism to recover. In addition, even though the industry has recovered well in the past from similar crises, the magnitude and scope of COVID-19-related effects on tourism and the economy make a speedy recovery unlikely. Efforts to assist in the tourism industries, which were hit badly by the pandemic, strive to create a sustainable and inclusive recovery.

\section{Limitations and Future Research}

Since the issue being investigated is an ongoing phenomenon, it was a mix of the information on the Malaysian situation from the mass media and scientific journal articles regarding the impact of coronavirus on global tourism overall and Malaysia in particular. In future research, the study could be extended by using empirical research methods to analyze the implications of COVID-19 on the tourism supply chain, either quantitatively or through qualitative case studies with various supply chain partners in Malaysia.

\section{References}

Abbas, J., Mubeen, R., lorember, P. T., Raza, S., \& Mamirkulova, G. (2021). Exploring the impact of COVID-19 on tourism: transformational potential and implications for a sustainable recovery of the travel and leisure industry. Current Research in Behavioral Sciences, 2, 100033. https://doi.org/10.1016/J.CRBEHA.2021.100033

Abdullah, S., Mansor, A. A., Napi, N. N. L. M., Mansor, W. N. W., Ahmed, A. N., Ismail, M., \& Ramly, Z. T. A. (2020). Air quality status during 2020 Malaysia Movement Control Order (MCO) due to 2019 novel coronavirus (2019-nCoV) pandemic. Science of the Total Environment, 729. https://doi.org/10.1016/j.scitotenv.2020.139022

Al-Rohaimi, A. H., \& Al Otaibi, F. (2020). Novel SARS-CoV-2 outbreak and COVID19 disease; a systemic review on the global pandemic. In Genes and Diseases (Vol. 7, Issue 4). https://doi.org/10.1016/j.gendis.2020.06.004

Beh, L. S., \& Lin, W. L. (2021). Impact of COVID-19 on ASEAN tourism industry. Journal of Asian Public Policy. https://doi.org/10.1080/17516234.2020.1871180

Brown, N. A., Rovins, J. E., Feldmann-Jensen, S., Orchiston, C., \& Johnston, D. (2017). Exploring disaster resilience within the hotel sector: A systematic review of literature. International 
Journal of Disaster Risk Reduction, 22. https://doi.org/10.1016/j.ijdrr.2017.02.005

Buckley, R. (2020). Conservation implications of COVID19: Effects via tourism and extractive industries. In Biological Conservation (Vol. 247). https://doi.org/10.1016/j.biocon.2020.108640

Chowdhury, I., \& Chhikara, D. (2020). Recovery strategy for tourism industry post-pandemic. Mukt Shabd Journal, 9(8).

Deb, S. K., \& Nafi, S. M. (2020). Impact of COVID-19 Pandemic on Tourism: Perceptions from Bangladesh. SSRN Electronic Journal. https://doi.org/10.2139/ssrn.3632798

DEMIR, M., DEMIR, Ş. Ş., DALGIÇ, A., \& ERGEN, F. D. (2021). Impact of COVID-19 pandemic on the tourism industry: An evaluation from the hotel managers' perspective. Journal of Tourism Theory and Research. https://doi.org/10.24288/jttr.857610

Faizal, A. M., Muhammad Azrai, A., \& Abdul Kadir, A. K. (2020). The The Impact of COVID-19 Pandemic on Oncofertility Services in Advanced Reproductive Centre UKM Medical Centre Malaysia. Asian Pacific Journal of Cancer Care, 5(S1). https://doi.org/10.31557/apjcc.2020.5.s1.165-166

Foo, L. P., Chin, M. Y., Tan, K. L., \& Phuah, K. T. (2020). The impact of COVID-19 on tourism industry in Malaysia. Current Issues in Tourism. https://doi.org/10.1080/13683500.2020.1777951

Hamid, M. A., \& Isa, S. M. (2020). Exploring the sustainable tourism practices among tour operators in Malaysia. Journal of Sustainability Science and Management, 15(1).

ILO. (2020). COVID-19 and employment in the tourism sector: Impact and response in Asia and the Pacific. COVID-19 and Employment in the Tourism Sector: Impact and Response in Asia and the Pacific.

Keeling, D. J. (2020). Restructuring Argentina's airline networks: Successes and challenges. Journal of Transport Geography, 86. https://doi.org/10.1016/j.jtrangeo.2020.102761

Lai, H. B. J., Zainal Abidin, M. R., Hasni, M. Z., Ab Karim, M. S., \& Che Ishak, F. A. (2020). Key adaptations of SME restaurants in Malaysia amidst the COVID-19 pandemic. International Journal of Research in Business and Social Science (2147- 4478), 9(6). https://doi.org/10.20525/ijrbs.v9i6.916

Mihajlovic, I. (2020). The impact of socio-economic changes in tourism on the business specialization of travel agencies. WSEAS Transactions on Business and Economics, 17. https://doi.org/10.37394/23207.2020.17.35

Muadz Samat. (2020). MOTAC ROLLS OUT RECOVERY PLAN IN COLLABORATION WITH INDUSTRY PLAYERS TO REVIVE MALAYSIA'S TOURISM SECTOR - Tourism Malaysia Corporate Site. Tourism.Gov.My.

Nizam, A., Talib, A., \& Alwani, A. (2020). An application of 'push and pull' domestic travel motivation model among young Malaysian adults : Post Covid-19. Journal of Humanities, Language, Culture and Business (HLCB), 4(15).

Perimbanayagam, K. (2020). Ministry has strategies for tourism recovery. New Strait Times.

Post, A. (2020). Safe Food Delivery In Malaysia. The Asean Post.

Razak, N. A. (2020). Health and tourism: Implications of COVID-19 pandemic to the Malaysian travel and hospitality industry. International Journal of Supply Chain Management, 9(4).

Ruiz, J. R. (2020). Green investments in the post covid-19 world and debt sustainability: The cases of france, italy and spain. Revista de Economia Mundial, 2020(56). https://doi.org/10.33776/rem.v0i56.4942

Salman, A., Kamerkar, U., Jaafar, M., \& Mohamad, D. (2021). Empirical analysis of COVID-19 induced socio cognitive factors and its impact on residents of Penang Island. 
International Journal of Tourism Cities. https://doi.org/10.1108/IJTC-05-2020-0091

Shukla, S. (2020). COVID-19 and Globalization, An Analysis. An International Multidisciplinary Double-Blind Peer-Reviewed Research Journal, 136(May).

Singh, A. K., \& Misra, A. (2020). Impact of COVID-19 and comorbidities on health and economics: Focus on developing countries and India. Diabetes and Metabolic Syndrome: Clinical Research and Reviews, 14(6). https://doi.org/10.1016/j.dsx.2020.08.032

Škare, M., Soriano, D. R., \& Porada-Rochoń, M. (2021). Impact of COVID-19 on the travel and tourism industry. Technological Forecasting and Social Change, 163. https://doi.org/10.1016/j.techfore.2020.120469

Uzir, M. (2019). Department of statistics Malaysia: Press release Malaysia economic performance fourth quarter 2020. In Department of Statistics Malaysia (Issue February).

Yeh, S. S. (2021). Tourism recovery strategy against COVID-19 pandemic. Tourism Recreation Research, 46(2). https://doi.org/10.1080/02508281.2020.1805933 